\title{
LA FUERZA INERCIAL DE LA COSTUMBRE
}

MARIANA TERÁN FUENTES

Facultad de Humanidades/Universidad Autónoma de Zacatecas

Francisco García González, Familia y sociedad en Zacatecas. La vida de un microcosmos minero novohispano, 1750 1830, México, El Colegio de MéxicoUAZ, 2000, 234 pp.

Las casas parecían mudas; los muros separaban las apariencias; las familias fueron enterradas, posiblemente olvidadas. Se nos olvidó cómo vestían, comían, dormían y rezaban. Dónde ponían sus lienzos y bultos sagrados, cuál era el espacio y el tiempo para rezar. Se nos olvidó que la familia no sólo se enrolaba en la minería, el comercio, la educación y la política, parecía que eran ámbitos ajenos al diario vivir. La casa y sus muros, los muros y los ornamentos, los ornamentos y el lujo, el lujo y la apariencia son prácticas que obligan a inscribir esa parte del pasado en la reciente historiografía para imaginar Zacatecas.

No se trata de explicar monumentos inertes ajenos a la vida cotidiana; tampoco de acercarse a lo extraordinario para olvidar las rutinas. El libro Familia y sociedad en Zacatecas. La vida de un microcosmos minero novohispano asume sus propios riesgos: el riesgo de darle vida al muro para sí, aunque el muro se encuentre agrietado, desdibujado. La riqueza que ofrece Francisco García González es pensar el muro para sí, lo que obliga al autor a describir el muro en sí. 
Los testamentos fueron una fuente privilegiada y espléndida para describir el muro en sí: la casa y sus medidas, los espacios y sus objetos, las fronteras, la distinción de los ámbitos: lo público y lo privado. El trabajo muestra formas y materiales de construcción, tipifica las casas y describe profusamente cómo los usos y costumbres se apoderan del espacio.

El muro empezó a mostrar no sólo sus grietas, cual implacables huellas del pasado, empezó a abrirse y permitió cercar la mirada. La mirada vio entonces un trazo borroso, pero indeleble; no pudo ocultarse la composición del muro y lo que celosamente velaba. La mirada logró vislumbrar el dibujo de un bodegón, de una mesa, de cocinas y cocineras, posiblemente se tratába de un cuadro sin título ni referencia, pero el trazo seguía en su continuo mudar, imaginando otros trazos que modelaban figuras; detrás del bodegón se evidenciaban enseres y formas de ubicar los objetos en un espacio como la cocina. Las cosas en sí no son más que cosas para sí. La cultura material sólo tiene sentido por quienes la fabrican, disponen y utilizan. Las cosas de una casa junto con la casa- son parte de un escenario de operaciones.
La mirada y el trazo asumieron riesgos de dibujar no sólo la cocina y sus fogones, el trazo empezó a dibujar la mano de las mujeres, a otras mujeres, a las mismas mujeres rodeadas de recetas, historias privadas, conversaciones y silencios. El trazo encontró entonces las cosas de las mujeres para hablar de ellas; de su estimable condición de mujer. El trazo ayudó a la mirada, pero la mirada, en su afán por observar, ya no pudo detenerse sólo en las cosas, en las casas, en los muros; se atrevió a mirar movimientos y no sólo objetos mudos e inertes. Detrás de lo inerte, la riqueza del movimiento. Las manos de las mujeres se metieron en la masa y moldearon formas irregulares en imágenes que apenas daban cuenta de un nuevo lienzo: la práctica del hollín. La descripción de las cosas permitió imaginar ruidos de cazones, luces y sombras de la cocina, enaguas que topaban rápidamente con las mesas, olores y sabores, apuros por atender a la dueña de la casa para que ésta a su vez dispusiera la mesa; permitió acercarse y conocer las formas acostumbradas de transmitir los saberes: de las abuelas a las madres, de éstas a sus hijas. 
La mirada caminó trémula para observar otras habitaciones menos humeantes, pero más frías. La sala y sus muebles era un espacio de convivencia, intercambio desde adentro con los de afuera. Espacio para conversar, saludar, socorrer. Era el puente entre lo público y las habitaciones íntimas. Hasta ahí era posible la entrada. Sin embargo, la mirada no se detuvo, caminó lentamente por los pasillos y llegó hasta las recámaras para observar el tiempo del descanso y la oración.

A pesar de que la mirada entró en el ámbito de lo privado, no olvidó los muros agrietados. Del otro lado del muro de la vida privada estaba la ciudad que crecía, se enfermaba, moría en insospechadas epidemias, rogaba en procesiones y actos públicos los favores de la Virgen y volvía a nacer fracturada con otras tantas familias interrumpidas. El trazo ayudaba a pensar otra confi guración, al lado de Rivera de Bernárdez, Elías Amador, Sonia Pérez Toledo, Mercedes de Vega.

Familia y sociedad en Zacatecas describe la ciudad del autor, su ciudad, sus hombres y sus cosas. La ciudad de Zacatecas ha sido acechada por miradas que obligan a reconocer su pasado y ponderar su extraordinaria riqueza cultural. La historiografía reciente sobre el periodo novohispano ha afinado la lente para explicar procesos económicos y demográficos del centro minero; se han apuntado algunos trabajos para dar cuenta de prácticas educativas y religiosas. Las nuevas corrientes que escriben sobre ese pasado han contribuido a pensar la ciudad no sólo por su movimiento económico y político, sino por su vida cotidiana. La vida de todos los días. Francisco García González ofrece en este libro una ventana para reconocer esa vida que no se agota más que en el vivir. El trabajo está orientado desde la perspectiva de la nueva historia social que dialoga con las fuentes para concebir nuevos temas, objetos y acercamientos. El nuevo objeto que el autor logró moldear fue un buen retrato de familia. Para ello es significativo hablar de su composición y dar cuenta del número de sus miembros, acercarse a la mujer, pero también al hombre, a sus atuendos, elecciones y modos de proponer una imagen ante la ciudad, a los objetos que forman parte de sus operaciones en el escenario de lo cotidiano. El trazo ayudó a pensar en los niños y en las niñas, corriendo el riesgo de la ausencia 
de una información documental que ofreciera más luz al respecto. Sin embargo, esta línea sólo queda sugerida... El resultado fue una excelente pintura donde aparece el muro, la mirada y el trazo.

A pesar de que la pintura que bien pudiera llamarse "Retrato de familia", la obra muestra cosas, disposiciones, hombres y mujeres, habitaciones y muros, es posible explicar lo invisible del trazo: la fuerza de la costumbre. Trazar las cosas y dibujar las familias implican la construcción de una figura, esto es, la configuración de la familia en el tiempo. El tiempo no es más esa denominación ausente de la vida cotidiana; es, en todo caso y acercándonos a la propuesta de Ortega y Gasset, una denominación intrínseca del hombre, de su devenir. Familia y sociedad en Zacatecas da figura a un marco de referencia temporal: la familia en el siglo XVIII.

Las costumbres son las inscripciones que hace el tiempo en las sociedades. Por costumbre podrá entenderse el modo como sutilmente los hábitos y prácticas se institucionalizan y llegan a ser ese escenario de operaciones al que me he referido, donde los grupos que se implican en él practican día tras día, a través de rutinas silenciosas, las convenciones sociales de una época. La actualización de esas convenciones son las maneras en como las familias construyen el espacio que asegure su costumbre, como lo llamara Michel de Certeau, "la fuerza inercial de la costumbre". Un hecho o acto particular, específico, se repite: los modos de cocinar y de comer, de vestir y adornarse, de suplicar y exigir, de lamentarse y renovarse; cada una de estas acciones se actualiza en el tiempo, es decir, se vive todos los días buscando configurar los anales de la familia, sus propios anales, al lado de las memorias de otras familias, lo que posiblemente llevaría a la construcción de un modelo de vida familiar. Lo que en el Zacatecas del siglo XVIII funcionaba como elemento de preeminencia bajo ciertos rituales de cortesía, ahora posiblemente resulte insignificante. Las actas de cabildo del periodo novohispano en la ciudad dan cuenta de las pequeñas minucias y pleitos por ganar la preeminencia ante Dios y la corona. La etiqueta y ceremonia así lo exigían. Pienso entonces en un juego dialéctico de ese diario vivir: no puede concebirse la costumbre sin los hábitos que la actualizan, pero tampoco es 
posible ubicar las acciones singulares sin esa referencia que le da sentido. Creo que ambas caras del mismo proceso están expuestas en este libro. El trazo, la mirada y el muro ayudaron a cercar "la fuerza inercial de la costumbre".

2 
